\title{
EVALUATION OF THE ANTIMALARIAL POTENTIAL OF STREPTOMYCES SP.
}

\author{
SWEETLINE C, USHA R* \\ Department of Microbiology, Karpagam Academy of Higher Education, Coimbatore - 641 021, Tamil Nadu, India. \\ Email: ushaanbu09@gmail.com
}

Received: 10 July 2017, Revised and Accepted: 21 November 2017

\section{ABSTRACT}

Objective: Isolate, screen and identify Streptomyces sp. from mangrove soil from pichavaram, Tamil Nadu, India, and study the molecular identification of selected Streptomyces sp. and check the antimalarial activity for the purified compound.

Methods: The16SrRNA secondary structure and the restriction sites of KMA08 were predicted using Genbank online software, respectively. Antiplasmodial activity of the $80 \%$ Ethyl acetate extract of Streptomyces sp. against chloroquine-sensitive Plasmodium berghei in mice using the 4 days suppression test was conducted. A total of 30 mice assigned to 5 groups of 6 animals each were infected with chloroquine-sensitive ( $P$. berghei) intraperitoneally. The Ethyl acetate extract (10, 20, and $30 \mathrm{ml} / \mathrm{kg}$ ), standard drug (chloroquine, $10 \mathrm{mg} / \mathrm{kg}$ ) and distilled water were administered orally daily for the treatment period. Percent Parasitemia was determined on the $5^{\text {th }}$ day from Giemsa stained smears obtained from tail vein and percent parasitemia suppression was calculated. Daily measurement of rectal temperature was also taken while body weight and packed cell volume were recorded on day 0 and 5.

Results: Results showed the extract produced a dose-dependent reduction in parasite density compared to the control group. Percept parasitemia calculation revealed $21.3,65.3$, and $80.5 \%$ inhibition at 10,20 , and $30 \mathrm{ml} / \mathrm{kg}$ of the extract, respectively.

Conclusion: The study revealed the present work indicated that Streptomyces sp. has as promising antiplasmodial activity against chloroquine sensitive P. berghei in a dose-dependent. As part of the drug discovery process, these promising finding may contribute to the medicinal and pharmaceutical field for malarial treatment.

Keywords: Actinomyces, Sequence, Antiplasmodial, Parasitemia, Malaria.

(C) 2018 The Authors. Published by Innovare Academic Sciences Pvt Ltd. This is an open access article under the CC BY license (http://creativecommons. org/licenses/by/4. 0/) DOI: http://dx.doi.org/10.22159/ajpcr.2018.v11i2.21230

\section{INTRODUCTION}

About 300-500 million clinical cases and 1.2-2.8 million deaths due to malaria occur each year $[1,2]$. The rising problems of resistance to the classical drugs (chloroquine and sulfadoxine pyrimethamine) $[3,4]$ and the problem of recrudescence of artemisinin stress the malaria can be in certain epidemiological circumstances a devastating disease with high morbidity and mortality demanding a rapid and comprehensive effort. The search for new antimicrobial agents is, therefore, crucial in the effort of combating the disease so need to look for new antimalarial agents [5]. Southeast Asia has been reported to have the greatest problem of drug resistance against malaria [6].

This situation is worsened with the emergence of chloroquineresistant strains of malaria parasite responsible for most of the death cases. Therefore, there is an urgent need to discover and develop new, effective and safe drugs for the treatment of this disease [7]. This has leads to attempt to discover other antimalarial agents, mainly from microbial sources. microorganisms, Streptomyces due to their capacity to produced novel bioactive secondary metabolites.

Among the microorganisms, Streptomyces were the most studied group due to their capacity to produce novel bioactive secondary metabolites. Despite their importance in soil ecology, the role of actinomycetes as potential antibiotic producers became apparent in 1940 , following the discovery of actinomycin [8], and was fully realized by the 1980s, when actinomycetes accounted for almost $70 \%$ of the world's naturally occurring antibiotics [9]. Although the exploitation of marine Streptomyces as a source for novel secondary metabolites is in its infancy, the discovery rate of novel secondary metabolites from marine Streptomyces has recently surpassed that of their terrestrial counterparts, as evident by the isolation of many different diverse structures in the past few years [6].

Furthermore, very few of these marine compounds have been tested against malaria parasites $[7,8]$. The aim of this study to investigate the antimalarial potential of mangrove Streptomyces from mangrove soil, whereby, an in vivo of the antiplasmodial properties of the Streptomyces species was determined.

\section{METHODS}

\section{Isolation of Actinomyces}

Soil samples were collected from four different area of Pichavaram mangrove, Tamil Nadu, India. The soil suspension $(0.5 \mathrm{ml})$ was spread on the starch casein agar plates. The plates were incubated for 4 weeks at $27^{\circ} \mathrm{C}$. The Actinomyces sp. colonies grown on Petri plates were counted at regular intervals. All the morphologically different Actinomyces sp. colonies were subcultured [10].

\section{Identification of isolated cultures}

Purified isolates of actinomycetes were identified using morphological and cultural characteristics by the methods as described Bergey's manual. The morphology of the spore-bearing hyphae with the entire spore chain, the structure and arrangement of the spore chain with the substrate and aerial mycelium of the actinomycetes were examined using slide culture technique and identified. After growth, the slide cultures were examined under light microscope [11]. 


\section{Molecular taxonomy}

Isolation of DNA and polymerase chain reaction (PCR) amplification

The isolated genomic DNA was amplified using two primers $16 \mathrm{~S}$ forward primer (5'-AGAGTRTGATCMTYGCTWAC-3') and 16S reverse primer (5'-CGYTAMCTTWTTACGRCT-3'). The final volume of reaction mixture of $100 \mu \mathrm{l}$ contained DNA $1 \mu \mathrm{l}, 16 \mathrm{~S}$ forward primer $400 \mathrm{ng}$, $16 \mathrm{~S}$ reverse primer $400 \mathrm{ng}$, dNTPs (2.5 mM each) $4 \mu \mathrm{l}, 10 \times$ Taq DNA polymerase assay buffer $10 \mu \mathrm{l}$, and Taq DNA polymerase enzyme $(3 \mathrm{U} / \mu \mathrm{l}) 1 \mu \mathrm{l}$ and water $\times \mu \mathrm{l}$. All PCR reagents were produced by chromous biotech. $10 \mu \mathrm{l}$ of sequencing reaction contain PCR reaction mix $4 \mu \mathrm{l}$, template $(100 \mathrm{ng} / \mathrm{ul}) 1 \mu \mathrm{l}$, primer $(10 \mathrm{pmol} / \lambda) 2 \mu \mathrm{l}$, and Milli $\mathrm{Q}$ water $3 \mu \mathrm{l}$. The amplification was performed on Eppendrof Thermocycler 96, according to the following promoter: An initial denaturation step at $96^{\circ} \mathrm{C}$ for $10 \mathrm{~s}$ followed 25 amplification cycles of $96^{\circ} \mathrm{C}$ for $1 \mathrm{~min}$, $96^{\circ} \mathrm{C}$ for $10 \mathrm{~s}, 50^{\circ} \mathrm{C}$ for $5 \mathrm{~s}$, and a final extension step of $60^{\circ} \mathrm{C}$ for $4 \mathrm{~min}$. The PCR product was detected by agarose gel electrophoresis and was visualized by ultraviolet fluorescence after ethidium bromide staining.

\section{Sequence similarities and phylogenetic analysis}

Nucleotide sequence of the 16S rRNA of strain KMA08 was determined and compared for similarity level with the reference species of actinomycetes contained in genomic database bank. The BLAST program (http://www.ncbi.nlm.nih.gov/blast) was employed to assess the degree of DNA similarity. Multiple sequence alignment and molecular phylogeny were evaluated using BioEdit software [12]. The phylogenetic tree was constructed using the BioEdit Mega5.5 software.

\section{Solvent extraction of Streptomyces species}

To the culture filtrate, equal volume of various solvents (n-butanol, ethanol, ethyl acetate, petroleum ether, chloroform, benzene, and xylene) was added separately and centrifuged at $5000 \mathrm{rpm}$ for $10 \mathrm{~min}$ to extract the active compound [13]. Active extract selected for the further studies.

\section{Experimental animals and parasite preparation}

Swiss albino mice (8-12 weeks, weighing 25-37 g) of either sex bred at the animal house of Karpagam Academic of Higher Education Coimbatore were used. The animals were kept at room temperature and were exposed to a 12-h light/dark cycle. All the experiments were conducted in accordance with the internationally accepted laboratory animal use, care and guideline [9]. The study was completed as per the guidelines of CPCSEA, Government of India, after approval from IAEC (IAEC no: KU/IAEC/Project 132. (21.09.2013)). For in vivo antimalarial assays of Streptomyces griseus extract, the mouse infective chloroquine-sensitive strain of Plasmodium berghei maintained at Karpagam Academic of Higher Education. The parasites were maintained by serial passage of blood from infected mice to non-infected ones on weekly basis.

\section{Animal management and grouping}

A slightly modified method described by Peters and Robinson, 1992 was used for this test. The mice were divided into five groups of six each and which were all infected with malaria parasites. The negative control was treated with the normal saline used for reconstitution, whereas positive control was treated with chloroquine $20 \mathrm{mg} / \mathrm{kg}$ (CQ10). The normal saline, the Streptomyces extract and the standard drug were administered orally. The dose level of the extract was selected to be $10 \mathrm{ml} / \mathrm{kg}, 20 \mathrm{ml} /$ $\mathrm{kg}$, and $30 \mathrm{ml} / \mathrm{kg}$ for mice after having considered the safety of the extract based on the information obtained from the toxicity study [14].

\section{Inoculation of mice}

Chloroquine-sensitive strain of $P$. berghei was obtained from the National Institute of Malaria Research, Delhi. Albino mice previously infected with $P$. berghei having variable parasitemia were used as a donor. The parasitemia of the donor mice was first determined [15]. The donor mice were then sacrificed by head blow, and blood was collected by cardiac puncture into heparinized vacutainer tube having $0.5 \%$ trisodium citrate added as an anticoagulant. The blood was then diluted with physiological saline $(0.9 \%)$. The dilution was made based on the parasitemia of the donor mice and the red blood cell (RBC) count of normal mice $(4.5 \times 10 \mathrm{RBC} / \mathrm{ml})[16,17]$ in such a way that $1 \mathrm{ml}$ blood contains $5 \times 10^{7}$ infected erythrocytes. Each mouse was administered intraperitoneally with $0.2 \mathrm{ml}$ of this diluted blood which contains $1 \times 10^{7}$ $P$. berghei infected erythrocytes. To avoid variability in parasitemia, the blood collected from all donor mice was pooled together. The parasite was maintained by weekly passage to the mice.

\section{Suppressive test (4 day)}

The method described by Trager and Jensen [18] with slight modification was used. Briefly, $3 \mathrm{~h}$ after inoculation of the parasite, the mice in the three treatment groups were administered with the extracts in doses of 10,20 , and $30 \mathrm{ml} / \mathrm{kg}$ for 4 consecutive days. Two control groups were used in the experiment, the negative control treated with normal saline for 4 consecutive days while the positive control administered chloroquine a standard antimalarial drug at $10 \mathrm{mg} / \mathrm{kg} /$ day. The drug, the normal saline and the extracts used in this study were administered by oral route with the aid of an oral gavage. Treatment was continued for 4 days: [19] Parameters rectal temperature was measured daily starting from day 0 (before infection and also after infection) till day 4 while body weight and packed cell volume (PCV) were taken at day 0 and day 5 using Wintrobe's method [20]. Then, parasitemia was measured on the 5 days.

\section{Evaluation of schizontocidal activity in established infection (Rane} test)

Rane test was employed to evaluate schizontocidal activity of extract in established infection [21]. On the $1^{\text {st }}$ day (D0), standard inoculum of $1 \times 10^{7}$ $P$. berghei infected erythrocytes were injected intraperitoneally into mice (Ryley et al.). $72 \mathrm{~h}$ later, the mice were divided into five groups of six mice each. Different doses of microbial extract $(10,20$, and $30 \mathrm{ml} / \mathrm{kg} /$ day $)$ were administered orally to these groups. Chloroquine $(10 \mathrm{mg} / \mathrm{kg} /$ day $)$ was given to the positive control group and an equal volume of normal saline to the negative control group. The drug/extract was given once daily for 5 days. Thin blood smears were prepared from tail of each mouse for 5 days, to monitor the parasitemia level.

\section{Determination of body weight and temperature}

The body weight of each mouse in all the groups was taken before infection and after infection. The rectal temperature of the mice was measured with a digital thermometer before infection, $3 \mathrm{~h}$ after infection and then daily up to day 4 to see the effect of the extracts on body temperature.

\section{PCV measurement}

PCV was measured to predict the effectiveness of the test extracts in preventing hemolysis resulting from increasing parasitemia associated with malaria, using Wintrobe method [22]

\section{Parasitemia measurement}

Blood smears from tail were applied on Menzel-Glaser microscope slides (Germany), fixed with absolute methanol and stained with $10 \%$ Giemsa stain at $\mathrm{pH} 7.2$ for 15 min [23]. The number of parasitized RBC was counted using Phase contrast microscopy with an oil immersion nose piece of $100 \times$ magnification power. Two fields were counted for each slide, the average was taken and percentage parasitemia was determined by analysis of variance (ANOVA) calculation [24,25].

\section{Statistical analysis}

The values were expressed as mean \pm SEM and $p<0.05$ was considered significant.

The statistical significance was assessed by one-way ANOVA followed by Tukey's comparison test for determining significance using computerized GraphPad Prism version 4.0, GraphPad software, U.S.A. The analysis was performed with $95 \%$ confidence interval [26].

\section{RESULTS AND DISCUSSION}

\section{Isolation and molecular characterization}

The soil samples collected from different areas of pichavaram, actinomycetes isolates were obtained in pure form and analyzed for their antibacterial activities. Totally 23 isolates were found to be Grampositive and showed branched mycelium in their cell morphology. 
Three isolates which exhibited activity against the pathogens were selected for the further studies. According to Bergey's manual of determinative bacteriology and the laboratory manual for identification of actinomycetes, the isolates were identified as Streptomyces sp (Fig. 1).

16S rRNA sequencing is a powerful tool for rapid identification and phylogenetic analysis of Streptomyces species. The obtained 16S rRNA nucleotide sequence was compared with available $16 \mathrm{~S}$ ribosomal sequences in the NCBI database using BLASTN (Fig.2). This isolate KMA08 has been enrolled into a Streptomyces sp. and was found to be closely related to Streptomyces strain with $99 \%$ sequence similarity. Hence, it was designated as Streptomyces sp. The submitted nucleotide sequence was provided a GenBank accession number KF913719. A fast minimum evolution analysis based on $16 \mathrm{~S}$ rRNA gene sequences revealed that the isolate KMA08 identified as S. griseus.

\section{In vivo antimalarial activity of $S$. griseus}

The crude extract of $S$. griseus displayed a very good activity against P. berghei (Table 1). The comparison analysis indicated that only two dose levels $(20 \mathrm{ml} / \mathrm{kg}$ and $30 \mathrm{ml} / \mathrm{kg})$ of the extract showed statistically significant $(\mathrm{p}<0.001)$ difference on the $5^{\text {th }}$ day parasitemia compared to the negative control. The $10 \mathrm{ml} / \mathrm{kg}$ dose level, however, showed a statistically non-significant reduction. Percentage inhibition analysis indicated that inhibition was dose-dependent with $21.3,65.3$, and $80.5 \%$ inhibition by Streptomyces sp. $10 \mathrm{ml}, 20 \mathrm{ml}$, and $30 \mathrm{ml}$ of the extracts, respectively, for the 4 day suppressive test $(\mathrm{p}<0.001$ in the latter two doses) when compared the negative control. When compared among themselves, 20 and $30 \mathrm{ml} / \mathrm{kg}$ showed a significant $(\mathrm{p}<0.001)$ percent parasitemia suppression than $10 \mathrm{ml}$. CQ10 had shown a statistically significant $(\mathrm{p}<0.001)$ inhibition compared to control as well as other doses with 10 and $20 \mathrm{ml} / \mathrm{kg}$. All the values are presented in Table 1.

Early malaria infection or Peters 4 days suppressive activity test for the Ethyl acetate extract of Streptomyces produced a dose-dependent suppression activity and was shown in Table 1 . The highest suppression of parasitemia was observed at the dose of $30 \mathrm{ml} / \mathrm{kg}$ body weight of mice. Percentage suppression was observed to increase as extract concentration increased. After 4 days treatment with the different extract doses, the mean parasitemia of the test groups ranged from $32.6 . \pm 1.0,25.4 \pm 0.6$, and $10.0 \pm 0.3 \%$ while the corresponding value of the negative control group being $62.4 \pm 1.2 \%$. The mice treated with CQ were completely free from the parasites on day 4 . The antimalarial activity produced by the extract was statistically significant $(\mathrm{p}<0.05)$ when related to control.

The result of the in vivo evaluation of the Streptomyces sp. extract on established infection showed a slight increase in suppressive activity. The extract was marginally active at $10 \mathrm{ml} / \mathrm{kg}$ per day and active at 20 and $30 \mathrm{ml} / \mathrm{kg}$ per day doses, respectively (Table 2). The mice that received $10 \mathrm{mg} / \mathrm{kg}$ of chloroquine per day, however, showed $100 \%$ suppression. The antimalarial activity produced by the extract was statistically significant $(\mathrm{p}<0.05)$ when related to control. All the values are presented in Table 2 .

Weight of $P$. berghei infected mice before and after treatment in the 4 day suppressive test

A body weight changes were observed between pre- and post-treatment days in all groups of mice treated with a crude extract of S. griseus. Treatment with crude extract of $S$. griseus prevented loss of weight associated with the increase Fig. 3 in parasitemia level at all the three dose levels compared to the negative control. However, the increase in body weight was found to be dose-dependent, the highest increment being caused by $10 \mathrm{ml} / \mathrm{kg}$ followed by $20 \mathrm{ml} / \mathrm{kg}$ and the least was by $30 \mathrm{ml} / \mathrm{kg}$. There were no detectable differences in preventing weight reduction associated with increasing parasitemia between different doses of the extract as well as between the extract and standard. In the 4-day suppressive test, all extract treated groups prevented body weight loss as compared to negative control. However, there were no significant differences in weight gain among extract treated groups.
The test extracts of $S$. griseus KF913719 prevented a loss of body weight in infected mice with increasing parasitemia. The comparison analysis indicated that the extracts significantly prevented weight loss at all dose levels compared to the controls. However, the increase in body weight was not found to be dependent on dose levels.

The effect of the test extract on body temperature of $P$. berghei infected mice was also observed (Table 3). Only the $10 \mathrm{ml} / \mathrm{kg}$ and $20 \mathrm{ml} / \mathrm{kg}$ dose level showed a statistically significant difference on body temperature change when compared to negative control $(\mathrm{p}<0.01)$ after the 4 days suppressive test. The analysis showed that at $20 \mathrm{ml} /$ $\mathrm{kg}$ and $30 \mathrm{ml} / \mathrm{kg}$ doses, the CQ10 $\mathrm{mg} / \mathrm{ml}$ and the negative control there was a reduction in rectal temperature. In all these groups, there was a relatively comparable non-preventive effect when compared to each other although the result was statistically significant. In the $10 \mathrm{ml} / \mathrm{kg}$, however, the rectal temperature seems to be maintained with only a slight rise at day 4 when compared to the day before infection. All the values are presented in Table 3 .

The analysis of PCV pre- and post-treatment, and an examinations of the rectal temperature indicated that the ethyl acetate extract of $S$. griseus was significantly prevent the reduction in PCV and body temperature, although, somewhat lesser percentages of reduction and significant preventive effects were observed, compared to the controls and dose levels.

Table 1: Effects of ethyl acetate extract of Streptomyces sp. on 4 day suppressive test

\begin{tabular}{lll}
\hline Treatment & \% Parasitemia & \% inhibition \\
\hline Normal saline $20 \mathrm{ml} / \mathrm{kg}$ (negative) & $62.4 \pm 1.2$ & 0 \\
CQ $10 \mathrm{mg} / \mathrm{kg}$ (control) & 0.0 & 100 \\
Extract $10 \mathrm{ml} / \mathrm{kg}$ & $32.6 \pm 1.0$ & 21.3 \\
Extract $20 \mathrm{ml} / \mathrm{kg}$ & $25.4 \pm 0.6$ & 65.3 \\
Extract $30 \mathrm{ml} / \mathrm{kg}$ & $10.0 \pm 0.3$ & 80.5 \\
\hline
\end{tabular}

Values are mean \pm SEM; one-way ANOVA followed by Tukey's multiple comparison tests. SEM: Standard error of mean, ANOVA: Analysis of variance

Table 2: Effects of ethyl acetate extract of Streptomyces sp. on established malaria infection

\begin{tabular}{lll}
\hline Treatment & \% Parasitemia & \% inhibition \\
\hline Normal saline $20 \mathrm{ml}$ & $63.5 \pm 1.0$ & 21.3 \\
CQ $20 \mathrm{ml}$ & $1.00 \pm 0.0$ & 100 \\
Extract $10 \mathrm{ml}$ & $35.6 \pm 1.0$ & 40.3 \\
Extract $20 \mathrm{ml}$ & $25.4 \pm 0.6$ & 50.3 \\
Extract $30 \mathrm{ml}$ & $10.0 \pm 0.3$ & 80.5 \\
\hline
\end{tabular}

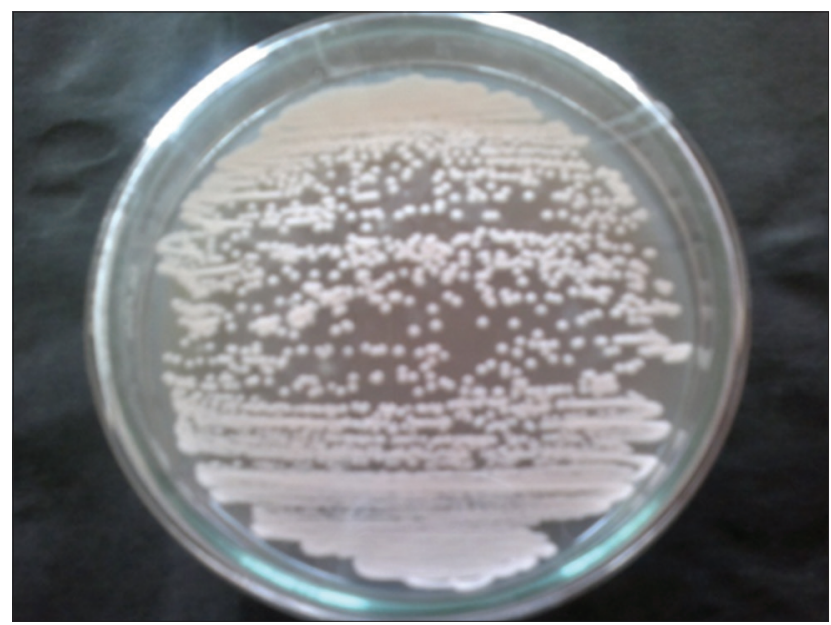

Fig. 1: Colonies after 1-week inoculation of Streptomyces sp. on Starch casein agar 
There was no statistically significant difference in the mean PCV on days 0 and 4 indicating that the extracts prevented significant PCV reduction (Table 4 ).

Statistical comparison of the effect of the extract on the study parameters (weight, PCV, and rectal body temperature) among groups at a fixed time and over time, have shown that extract administration did not cause significant change on any of these parameters. The present determination of antimalarial effect of the $S$. griseus extract is additional proof of its medicinal values, and it can, thus, be assumed that the extract can be safe at the dose levels used in the study [27]. According to Saxena et al. [27] and Ramazan et al. [28], several classes of secondary metabolites are responsible for the antimalarial activity, the antimalarial activities exhibited by this extract may also be due to the presence of other active compounds.

An in vivo antiplasmodial activity can be classified as moderate, good and very good if an extract displayed a percent parasite suppression equal to or $>50 \%$ at a dose of 30,20 and $10 \mathrm{ml} / \mathrm{kg}$ body weight per day. Based on this classification, the extract of $S$. griseus exhibited a good antiplasmodial activity. Anemia, hypoglycemia, body weight loss, and body temperature reduction are the general features of malaria-infected mice body weight loss is one feature of rodent malaria infections [29]. The result of the present work, however, showed only a statistically nonsignificant slight gain in body weight of crude extract administered of $P$. berghei infected mice. This could possibly be due to depressing effect of the crude extract on feed intake/appetite. Mice treated with crude extract of $S$. griseus showed a lower body weight pattern as compared with the non-treated ones which are in agreement with this result.

According to Taylor and Hurd [30], the effect of rodent malaria on PCV as measured by hematocrit was parasite-induced fall down to $42-43 \%$, which occurred approximately $48 \mathrm{~h}$ post-infection. $P$. berghei infected mice suffer from anemia due to RBC destruction, either by parasite multiplication or by spleen reticuloendothelial cell acts as the presence of many abnormal RBC stimulates the spleen to produce many phagocytes [31]. The significant decrease in PCV could be attributed to the presence of antinutritive factors in the crude extract. Plasmodium infection is correlated with the incidence of the high destruction of red blood cells, hence anemia which could be life-threatening [32]. In this study, the extract prevented significant PCV reduction in a dosedependent manner. A decrease in the metabolic rate of infected mice occurred just before death and was accompanied by a corresponding decrease in internal body temperature [33]. In this study, however, the extract prevented significant body temperature reduction in a dosedependent manner. This could be attributed to the effect of the extract as it may have a hypothermic effect on the treated mice.

\section{CONCLUSION}

The extract used in this study showed considerable antimalarial activities that are worth to be investigated. Further studies are

Table 3: Rectal temperature of $P$. berghei infected mice before and after treatment in the 4 days suppressive test

\begin{tabular}{llllll}
\hline Group & Before infection & 3 h after infection & D-2 & D-3 & D-4 \\
\hline Normal saline $(10 \mathrm{ml} / \mathrm{kg})$ & $35.12 \pm 0.47$ & $36.66 \pm 0.36$ & $37.09 \pm 0.22$ & $38.12 \pm 0.37$ & $38.76 \pm 0.25$ \\
CQ $(10 \mathrm{mg} / \mathrm{kg})$ & $35.84 \pm 0.42$ & $37.22 \pm 0.54$ & $37.12 \pm 0.65$ & $37.6 \pm 0.46$ \\
Extract $(10 \mathrm{ml} / \mathrm{kg})$ & $35.27 \pm 0.18$ & $37.18 \pm 1.30$ & $37.54 \pm 0.13$ & $37.22 \pm 0.10$ & $37.6 \pm 0.23$ \\
Extract $(20 \mathrm{ml} / \mathrm{kg})$ & $35.43 \pm 0.15$ & $37.65 \pm 0.15$ & $37.97 \pm 2.28$ & $37.38 \pm 01$ & $37.32 \pm 0.08$ \\
Extract $(30 \mathrm{ml} / \mathrm{kg})$ & $36.22 \pm 0.33$ & $36.39 \pm 0.26$ & $37.160 \pm 0.31$ & $36.53 \pm 0.18$ & $36.1 \pm 0.33$ \\
\hline
\end{tabular}

Values are represented as mean \pm standard error of mean. Statistical analysis performed using one-way analysis of variance followed by turkey test.

P. berghei: Plasmodium berghei

Table 4: PCV of $P$. berghei infected mice before and after treatment in the 4 days suppressive test

\begin{tabular}{llll}
\hline Treatment & Pre-treatment PCV & Post-treatment PCV & Percentage change \% \\
\hline Negative control $(10 \mathrm{ml} / \mathrm{kg})$ & $51.55 \pm 1.51$ & $44.85 \pm 1.62$ & -9.87 \\
CQ $(10 \mathrm{mg} / \mathrm{kg})$ & $59.65 \pm 1.25$ & $25.08 \pm 0.66$ & -3.30 \\
Extract $(10 \mathrm{ml} / \mathrm{kg})$ & $41.43 \pm 1.66$ & $35.4 \pm 0.63$ & 2.55 \\
Extract $(20 \mathrm{ml} / \mathrm{kg})$ & $40.2 \pm 1.35$ & $29 \pm 0.66$ & -0.97 \\
Extract $(30 \mathrm{ml} / \mathrm{kg})$ & $45.78 \pm 1.34$ & $27.43 \pm 1.45$ & -4.89 \\
\hline
\end{tabular}

Values are represented as mean \pm standard error of mean. Statistical analysis performed using one-way analysis of variance followed by turkey test. P. berghei: Plasmodium berghei, PCV: Packed cell volume

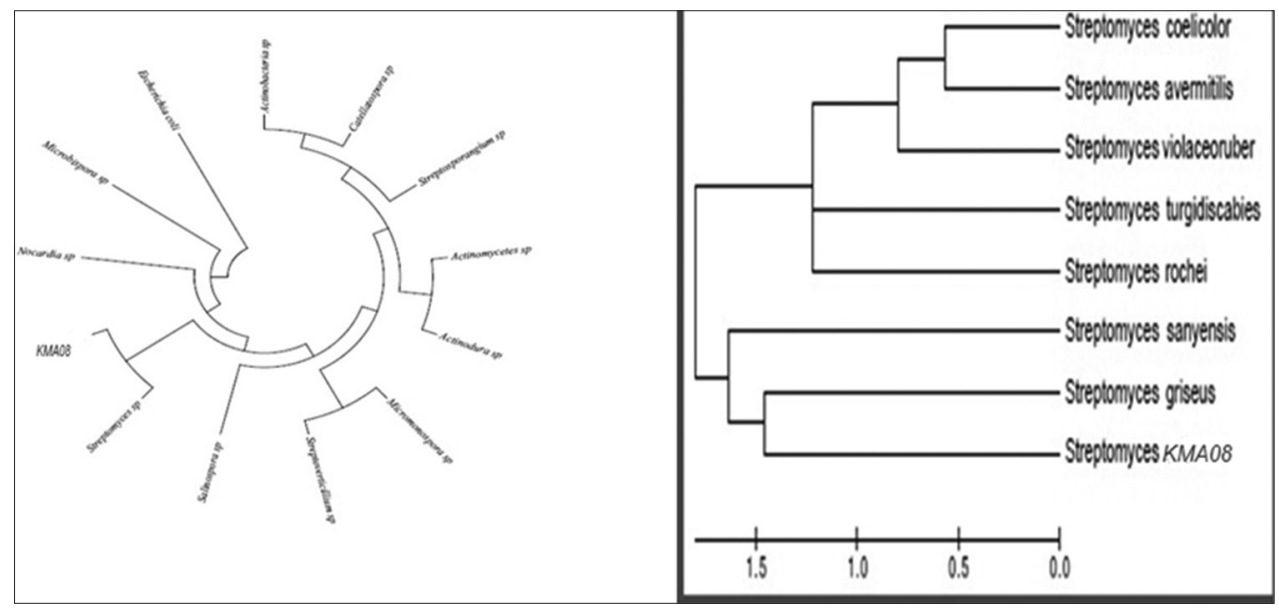

Fig. 2: Phylogenetic analysis of Streptomyces griseus KF913719 (KMA08) 


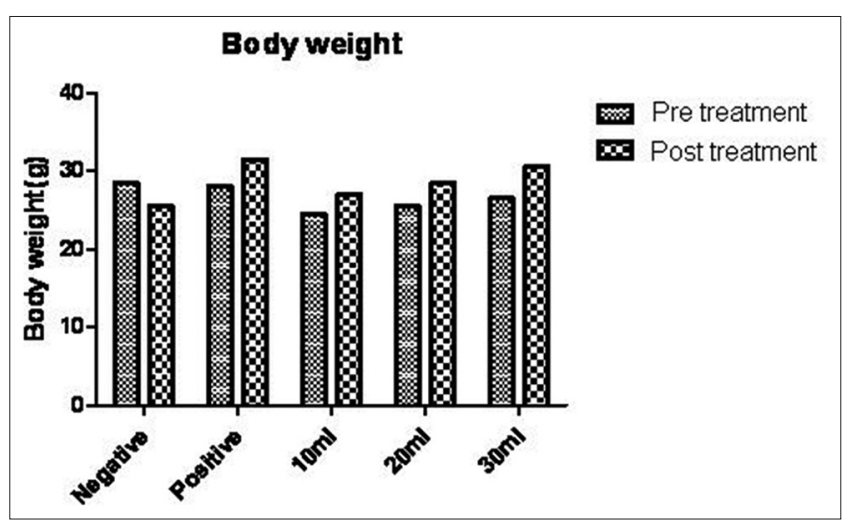

Fig. 3: Body weight of Plasmodium berghei infected mice before and after treatment in the $\mathbf{4}$ days suppressive test

suggested to elucidate their antimalarial properties and also to isolate the active substance(s) responsible for their antimalarial activity. The current antimalarial drugs have their own problems to prevent and treat human malaria. The results of this study indicated no toxicity in mice with an even high dose of S. griseus KF913719 solvent extract, which confirm its lowest effects. The results of the study indicated that in vivo, Ethyl acetate extract of S. griseus KF913719 displayed a very good activity against the P. berghei malaria parasite. Rivo et al. [34] observed that ethyl acetate extracts of Streptomyces sp. showed higher antiplasmodial activity. Kondrashin et al. [35] in their study showed ethyl acetate extracts of Streptomyces sp. had maximum plasmodial activity. However, although the results clearly indicated that the test extract of S. griseus KF913719 significantly prevented weight loss at all dose levels compared to the control, the increase in body weight is not consistent with increasing dose of the extracts. It may possibly indicate the appetite suppressive effects of the extracts, which would reasonably increase with increasing dose.

\section{ACKNOWLEDGMENT}

The authors are sincerely grateful to the management, Karpagam Academic of Higher Education, Coimbatore, Tamil Nadu, India - 641021 , for encouragement and support.

\section{REFERENCES}

1. Guadalupe E, Garcia L, Rodriguez JB. Current status and progress made in malaria chemotherapy. Curr Med Chem 2007;14:289-14.

2. Sahu NK, Sahu S, Kohli DV. Novel molecular target for antimalarial drug development. Chem Biol Drug Design 2008;71:287-97.

3. Basco LK, Mitaku S, Skaltsounis AL, Ravelomantosa N, Tillequin F, Koch $\mathrm{M}$, et al. In vitro activities of furoquinoline and acridone alkaloids against P. falciparum. Antimicrob Agents Chemother 1994;38:1169-71.

4. Ibezim EC, Odo U. Current trends in malaria chemotherapy. Afr J Biotechnol 2008:7:349-56

5. Ridley RG. Medical need, scientific opportunity and the drive for antimalarial drugs. Nature 2002;415:686-93.

6. World Economic Forum. Guidelines for Employer-Based Malaria Control Programmes. Massachusetts, USA: Global Health Initiatives and Harvard School of Public Health; 2006.

7. Sweetline $\mathrm{C}$, Usha $\mathrm{R}$, Dhanabalan $\mathrm{R}$, Palaniswamy M. In vivo antimalarial activity of Streptomyces sp against Plasmodium berghei in mice model. Int J Curr Res 2014;6:7617-20.

8. Min Chung, Seo S, Kang E, Park O, Moon H. Anti-malarial activity of 6-(8'Z-pentadecenyl)-salicylic acid from Viola websteri in mice. Malar J 2007;8:151.

9. Waksman SA, Woodruff HB. Bacteriostatic and bacteriocidal substances produced by soil actinomycetes. Proc Soc Exp Biol Med 1940;45:609-14

10. Pavani M, Girijasankar G, Mallika K, Sagar GV. Purification and molecular weight determination of Keratinase isolated from Streptomyces malaysiensis. Int J Pharm Pharm Sci 2017;9:154-8.

11. Cooks AE, Meyers PR. Rapid identification of filamentous actinomycetes to the genus level using genusspecific 16S rRNA gene restriction fragment patterns. Int J Syst Evol Microbiol 2003;53:1907-15.

12. Coombs JT, Franco CM. Isolation and identification of actinobacteria from surface sterilized wheat roots. Appl Environ Microbiol 2003;69:5603-8.

13. Eltayeb IM, Hami AS. Phytochemical screening and antimicrobial activity of Thuja occidentalis seeds extracts against the isolated common skin infecting microorganisms. Int J Pharm Pharm Sci 2017:9:20-4.

14. Peters W, Robinson B. The chemotherapy of rodent malarial. Studies on puronaridine and other manich base antimalarials. Ann Trop Med Parasitol 1992;86:455-65.

15. WHO. Control and Surveillance of African Trypanosomosis. Switzerland, Geneva: World Health Organization Technical Report Series No. 881; 1998.

16. David A, Fidock M, Philip J, Rosenthal L, Croft L, Reto B, et al. Antimalarial drug discovery: Efficacy models for compound screening. Protocols for antimalarial efficacy testing in vivo. Nat Rev 2004;3:28.

17. Peters W, Robinson B. Experimental models in antimicrobial chemotherapy. In Handbook of Animal Models of Infection. London: Elsevier Ltd.; 1999. p. 757-73.

18. Waako PJ, Gumede B, Smith P, Folb PI. The in vitro and in vivo antimalarial activity of Cardiospermum halicacabum L. and Momordica foetida schumch. Et thonn. J Ethnopharmacol 2005;99:137-43.

19. Mosmann T. Rapid colorimetric assay for cellular growth and survival: Application to proliferation and cytotoxicity assays. J Immunol Methods 1983;65:55-63.

20. Lambros C, Vanderberg JP. Synchronization of Plasmodium falciparum erythrocytic stages in culture. J Parasitol 1979;65:418-20.

21. Abebe D, Debella A, Urga K. Medicinal plants and other useful plants of Ethiopia. ENHRI. Nairobi: Camerapix Publishers International; 2003. p. 299-301.

22. Geyid A, Abebe D, Debella A, Makonnen Z, Aberra F, Teka F, et al. Screening of some medicinal plants of Ethiopia for their antimicrobial properties and chemicals profiles. J Ethnopharmacol 2005;97:421-7.

23. Yineger H, Kelbessa E, Bekele T, Lulekal E. Ethnoveterinary medicinal plants at bale mountains national park, Ethiopia. J Ethnopharmacol 2007; 112:55-70.

24. Vasant RA, Narasimhacharya AV. Antihyperglycemic and antihyperlipidemic effects of Mangifera indica L. In fluoride induced toxicity. Phamacol Online 2011;3:265-74

25. Dikasso D, Makonnen E, Debella A, Abebe D, Urga K, Makonnen W, et al. In vivo antimalarial activity of hydroalcoholic extracts from Asparagus africanus Lam. in mice infected with Plasmodium berghei. Ethiop J Health Dev 2006;20:112-8.

26. Saxena S, Pant N, Jain DC, Bhakuni RS. Antimalarial agents from plant sources. Curr Sci 2003;85:1314-29.

27. Ramazani A, Zakeri S, Sardari S, Khodakarim N, Djadid N. In vitro and in vivo antimalarial activity of Boerhavia elegans and Solanum surattense. Malar J 2010;9:124.

28. Perlmann P, Troye-Blomberg M. Malaria Immunology. Stockholm, Sweden: Karger Publisher; 2007.

29. Taylor PJ, Hurd H. The influence of host haematocrit on the blood feeding success of Anopheles stephensi: Implications for enhanced malaria transmission. Parasitology 2001;122:491-6.

30. Chinchilla M, Guerrero OM, Abarca G, Barrios M, Castro O. An in vivo model to study the anti-malaric capacity of plant extracts. Rev Biol Trop 1998;46:35-9.

31. Jigam A, Akanya H, Bukar E, Obadoyi E. Antiplasmodial, analgesic and anti-inflammatory effects of Crude Guiera senegalensis Gmel Combretaceae Leaf extracts in mice infected with Plasmodium berghei. J Pharm Phytother 2011;3:150-4.

32. Hansen B, Pappas P. Effect of P. Berghei on the metabolic rate of mice. Ohio J Sci 1977;77:189-91.

33. Handayani S, Chiu D. T, Tjitra E . High deformability of Plasmodium vivax-infected red blood cells under microfluidic conditions. Journal of Infectious Diseases 2009; vol. 199, no. 3, pp. 445-450.

34. Rivo Y.B, Alkarimah A, Ramadhani N.N, Cahyono A.W, Laksmi D.A, Winarsih S, Fitri L.E. Metabolite extract of Streptomyces hygroscopicus Hygroscopicus inhibit the growth of Plasmodium berghei through inhibition of ubiquitin - proteasome system. Trop Biomed 2013; 30(2): 91-300.

35. Kondrashin AV, Rooney W. Overview: epidemiology of malaria and its control in countries of the WHO South-East Asia region. Out heast Asian J Trop Med \& Public Health 1992; 23: 13-22. 